\title{
Leader-Member Exchange and Stress: The Mediating Role of Job Involvement and Role Conflict
}

\author{
Ericka R. Lawrence \\ East Carolina University \\ K. Michele Kacmar \\ University of Alabama
}

\begin{abstract}
Research examining the influence of leader-member exchange (LMX) on employee outcomes is plentiful. However, research exploring the negative consequences of high-quality LMX relationships has been limited. This research posits, tests, and then replicates a model in which role conflict and job involvement mediate the relationship between LMX and stress. Results from a sample of 418 organizational employees of a water management district indicate that both role conflict and job involvement partially mediate the relationship between LMX and stress. Additionally, both role conflict and job involvement were found to fully mediate the relationship between LMX and stress in a sample of 134 employees from a state lottery commission. Strengths, limitations, practical implications, and directions for future research also are presented.
\end{abstract}

Key words: leader-member exchange (LMX), stress, role conflict, job involvement

\section{Introduction}

Leader-member exchange (LMX) theory describes the role making process that results in leaders developing different relationships with their followers (Dansereau, Graen \& Haga, 1975). Specifically, a leader may establish low-quality exchange relationships with some followers and high-quality relationships with others. Low LMX relationships are purely economic (Blau, 1964) and based on the employment contract. On the other end of the continuum, high LMX relationships are characterized by high levels of trust, interaction, and support (Dienesch \& Liden, 1986).

The benefits of high-quality leader-member exchange relationships have been well documented (Gerstner \& Day, 1997). Subordinates who enjoy a high-quality LMX relationship have higher job satisfaction and autonomy, and receive more formal and informal rewards than those in low-quality LMX relationships (Gerstner \& Day, 1997; Dienesch \& Liden, 1986). These individuals also experience increased levels of organizational commitment (Chuang \& Shon, 2008; Liden \& Maslyn, 1998), decreased turnover intentions (Harris, Harris \& Brouer, 2009; Liden \& Maslyn, 1998), and engage in increased levels of organizational citizenship behaviors (Anderson \& Williams, 1996; Deluga, 1998; Rupp \& Cropanzano, 2002).

Clearly, previous work in this area has broadened our understanding of the benefits of participating in high-quality LMX relationships. However, since LMX is based on the negotiation of roles between supervisors and subordinates, it is possible that role-related problems may occur (Hochwarter \& Byrne, 2005). For instance, Harris and Kacmar (2006) found a curvilinear relationship between LMX relationshipquality and stress that indicated that individuals reported an increase in experienced stress as LMX quality increased. Previous research also has found that high-quality LMX subordinates experience lower levels of stress (Schriescheim, Castro, \& Cogliser, 1999) due to the reduction or elimination of role stressors, such as ambiguity and role conflict, and through the increased support and information received from their supervisors (Kacmar, Witt, Zivnuska, \& Gully, 2003; Lagace, Castleberry, \& Ridnour, 1993; Nelson, Basu, \& Purdie, 1998). However, high-quality LMX does not reduce role overload and time pressure for these individuals (Nelson, et al. 1998). Although these findings indicate the possibility of negative consequences resulting from participating in high-quality LMX relationships, research in this area has been limited and the conflicting findings should be examined (Harris \& Kacmar, 2006; 
Hochwarter \& Byrne, 2005). To address this gap in the literature, scholars have suggested that future LMX researchers explore the process that results in high-quality LMX members experiencing higher levels of stress (Harris \& Kacmar, 2006) and to broaden our understanding of the influence of LMX on organizational outcomes such as health, commitment, and performance (Gerstner \& Day, 1997). Towards this end, the purpose of this research is to examine the role demands that result in high levels of stress for high-quality LMX members. Specifically, this study replicates previous research examining role conflict as a mediator of the LMX and stress relationship and extends extant research by considering job involvement as a mediator of the LMX and stress relationship for those in high-quality exchange relationships. A graphical depiction of the model is presented in Figure 1.

Figure 1

The mediating effects of role conflict and job involvement on the relationship between LMX and stress.

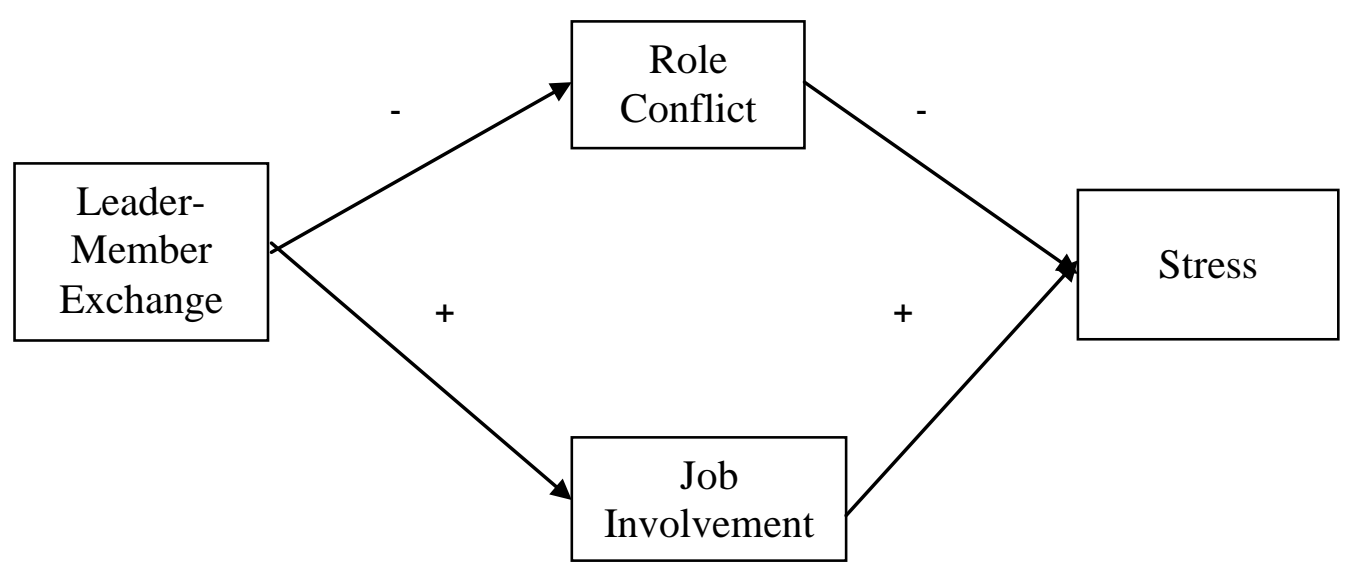

This study contributes to the literature by examining a new perspective on LMX quality. A majority of the research published on LMX quality indicates that high-quality relationships provide a variety of positive benefits to subordinates (Gerstner \& Day, 1997). We extend LMX theory by investigating the potential negative consequences of participating in high-quality LMX relationships. There are also several practical benefits from understanding the causes and consequences of stress in the workplace. First, the staggering costs of stress-related illnesses to the American economy have been estimated at approximately $\$ 300$ billion (American Institute of Stress, 2007). Second, there have been increased findings of negative physical outcomes related to workplace stress. These outcomes include frustration, depression, and various physical ailments (Ganster \& Schubroeck, 1991; Jex \& Beehr, 1991). Finally, organizational costs related to stress have increased due to higher accident levels, lost time, and reduced productivity (Ganster \& Schaubroeck, 1991).

\section{Theoretical Background and Hypotheses Development}

LMX theory is based on the concepts of role making and social exchange. Graen and his colleagues (Dansereau, Cashman \& Graen, 1973; Dansereau, Graen, \& Haga, 1975; Graen, 1976; Graen \& Cashman, 1975) used the role episode model from Kahn, Wolfe, Quinn, Snoek, and Rosenthal (1964) to explain the LMX process. Overall, the role-making process involves an initial testing period where the leader evaluates the degree to which sent roles are accepted or rejected by a new member. The degree to which the member's task performance satisfies the leader's role requests impacts the type of LMX relationship that develops.

Supervisors in low-quality LMX relationships provide minimal - if any- additional benefits or advantages to their subordinates. Therefore, lower expectations exist regarding the quality of exchange or feelings of obligation in these relationships. Specifically, supervisors in low-quality LMX relationships anticipate and engage in exchanges that are based on the formal employment contract (Liden et al. 1997). Thus, 
subordinates in low-quality LMX relationships feel obligated to complete only those tasks that the formal job description requires (Gouldner, 1960).

On the other hand, the concepts of social exchange and the norm of reciprocity (Blau, 1964) have been widely used to describe the underlying basis of the development of supervisor-subordinate relationships (Graen \& Cashman, 1975; Uhl-Bien \& Maslyn, 2003). Social exchange theory posits that the positive, voluntary actions that supervisors direct toward subordinates will contribute to the development of highquality exchange relationships and create a feeling of obligation on behalf of the subordinate to reciprocate in an equally positive manner (Blau, 1964; Gouldner, 1960). As the quality of LMX increases, supervisors provide more support and resources to their subordinates in various tasks that enhance career development (Chen, 2007). These positive contributions essentially create obligations for the subordinate to reciprocate. One form of pay back may be performing more effectively. Therefore, subordinates directly reciprocate the benefits they have received by competently executing their job responsibilities to maintain a high-quality LMX relationship with trust, respect, and mutual obligation as the foundation (Settoon et al., 1996; Uhl-Bien \& Maslyn, 2003).

\section{$\underline{\text { LMX and Role Conflict }}$}

Previous research has given considerable attention to the ways that roles impact employee behavior (Jackson \& Schuler, 1985; Katz \& Kahn, 1978). Role theory suggests that individuals generally behave in ways that are consistent with how their roles are defined (Kahn et al., 1964). Role theory also posits that interrole conflict and tension often occur when it becomes difficult for individuals to successfully perform their various roles because of constrained resources (e.g., time or energy). On the basis of role theory and the extant literature (Tanner, Dunn, \& Chonko, 1993; Nelson, Basu, \& Purdie, 1998), this research proposes that employees involved in high-quality LMX relationships experience lower levels of role conflict then low-quality LMX members as these members receive adequate information, communication, and assistance from their supervisors to prioritize their roles.

Hypothesis 1: There is a negative relationship between LMX quality and role conflict.

\section{$\underline{\text { LMX and Job Involvement }}$}

Job involvement refers to the degree to which individuals identify with, or give to, the job (Kanungo, 1982). Highly involved employees often consider their jobs to be highly connected with their identity, interests, and life goals. Specific attributes of the work situation itself may result in subordinates being more involved in their jobs (Mudrack, 2004). For example, a subordinate's belief that the organization values his or her work may encourage their strong identification with the workplace (Eisenberger, Fasolo, \& Davis-LaMastro, 1990).

As previously indicated, subordinates who engage in high quality LMX relationships receive benefits that are not afforded to their low-quality LMX peers (Graen \& Scandura, 1987). Social exchange theory suggests that in exchange for the advantages that high-quality LMX subordinates receive, supervisors will expect these subordinates to perform tasks that are not included in the formal job description in addition to tasks that the job requires. Furthermore, the norm of reciprocity (Gouldner, 1960) suggests that individuals may feel obligated to assist those who have assisted them. Therefore, subordinates in highquality LMX relationships will feel obligated to assist their supervisors, who have provided them with additional benefits. Through fulfilling their obligations, subordinates in high-quality LMX relationships will experience a high level of job involvement.

On the other hand, low-quality LMX members receive few, if any, additional benefits from their supervisors. Therefore, these members should have reduced expectations for exchange or feelings of obligation towards the supervisor. Specifically, supervisors in low-quality LMX relationships engage in interactions that follow employment contract requirements (Cropanzano \& Mitchell, 2005; Gerstner \& Day, 1997). Therefore, subordinates in low-quality LMX relationships feel obligated to only perform the tasks that are presented in the formal job description and are unlikely to experience high levels of job involvement. 


\section{LEADER-MEMBER EXCHANGE AND STRESS}

Hypothesis 2: There is a positive relationship between LMX quality and job involvement.

\section{$\underline{\text { Stress }}$}

While the definition of stress has been a topic of interest for many years, the construct generally can be defined as an "aversive or unpleasant emotional and physiological state resulting from adverse work experiences, particularly experiences that are uncertain or outside the employee's control" (Judge \& Colquitt, 2004). Work experiences that result in stress are often referred to as stressors, while the effects of stress, as related to health and employee behavior, are referred to as strain (Hart \& Cooper, 2001; Kahn \& Byosiere, 1992). Previous research has examined various stressors, including aspects of the employee's role, specific job demands and characteristics, and aspects of the physical work environment (Hart \& Cooper, 2001; Kahn \& Byosiere, 1992).

Experiencing stressors can be positive for individuals to the extent that it motivates them to accomplish their work-related tasks. However, when an employee's job roles and demands become overwhelming, negative consequences can occur. Researchers have suggested that role conflict is linked to a number of negative outcomes, including psychological strain and job dissatisfaction (Rizzo, House \& Lirtzman, 1970; Schaubroeck, Cotton, \& Jennings, 1989). As previously discussed, when two or more sets of role pressures exist in an individual's work environment and the compliance with any of these pressures hinders the accomplishment of another, role conflict occurs (Kahn et al., 1964). Experiencing incompatible expectations that are associated with multiple roles, or with a single role, can be psychologically uncomfortable for individuals due to the lack of uncertainty or control that they may experience.

Specifically, role conflict is directly influenced by LMX quality. A subordinate in a high-quality LMX relationship will experience low levels of role conflict as a result of the increased supervisor support and communication that they receive as compared to a subordinate in a low-quality LMX relationship. This decreased level of role conflict will subsequently lead to decreased levels of stress for subordinates in high-quality LMX relationships. Consistent with theory and previous research, we hypothesize the following:

Hypothesis 3: Role conflict mediates the relationship between LMX quality and stress.

\section{$\underline{\text { Job Involvement and Stress }}$}

Previous research has found that a positive relationship exists between job involvement and effort, various aspects of job satisfaction, organizational commitment, and low turnover intentions (Brown, 1996). However, there are also negative side effects of high job involvement. Individuals who have a high level of job involvement experience an increased emotional investment and identity with the work role. This increased emotional investment in the work role includes increased time and energy focusing on the work role and can include behaviors such as, taking work home or continuing to think about unfinished tasks at work and how they will be completed on the next day (Janssen, 2003). For example, individuals with high job involvement were found to have high levels of work-family conflict (Carlson \& Perrewe, 1999; Parasurman \& Simmers, 2001), whose underlying premise is stress. Therefore, it is likely that individuals with high job involvement experience stress as a result of their increased emotional investment and identification with their jobs. In conjunction with LMX, subordinates in high-quality LMX relationships are more likely to be highly involved in their jobs as a result of the increased levels of support, trust, and obligation that evolve from these relationships. This increased level of job involvement will result in increased levels of stress.

Hypothesis 4: Job involvement mediates the relationship between LMX quality and stress.

\section{Methodology}




\section{Procedure and Sample 1}

Top management from a water management district in the southeastern United States requested the administration of a survey to determine employees' feelings about the organization. A company memo was distributed to all employees notifying them of the opportunity to participate in the survey. Participation in the survey was voluntary and respondents were assured that their responses were both confidential and anonymous. To assure confidentiality and anonymity, survey administration was held on site. The surveys were administered during regular working hours over a three day period in groups of up to 50 . Employees were told the purpose of the study and provided a written survey to complete. To protect employees with unique characteristics, respondents were asked not to provide their names and limited demographic data were collected. Respondents placed their completed surveys in a locked collection box that was always manned by the researchers.

This sample consisted of 418 employees (a response rate of $60 \%$ ). The respondents were predominantly male (55\%), and Caucasian ( $81 \%)$. The average age of the respondents was 40.9 years with a range from 22 to 76 years. Tenure data were measured categorically, with responses being grouped in three year blocks (i.e., 0-2 years, 3-5 years, 6-8 years, etc.) based on concerns about respondent anonymity. Respondents indicated that $244(60 \%)$ had worked for the organization between three and nine years, 99 $(22 \%)$ had tenure over nine years, and the remaining $62(15 \%)$ had been employed with the company for less than three years.

\section{Procedure and Sample 2}

Data were collected from sample 2 through the distribution of surveys to employees of a state lottery commission in the southern United States. The survey included a letter signed by the director of the agency that highlighted the importance of the accuracy and timeliness in completing the survey. The director also guaranteed the confidentiality of the responses and the employees were allowed to complete the surveys during work hours. Approximately 2 and 4 weeks after the surveys were administered, the director sent follow-up emails to all employees reminding them to complete the surveys. The completed surveys were mailed directly to the researchers.

This sample consisted of 134 employees (a response rate of 39\%). These employees lived in various locations throughout the state. Respondents held a variety of positions within the organization (i.e. advertising, finance, and disbursement). The average age of the respondents was 43.75 years with a range from 22 to 71 years. Employee tenure in the organization ranged from 1 to 11 years with a mean of 6.4 years. The respondents were predominantly female (54\%), and Caucasian (72\%).

\section{Measures}

All of the survey items were responded to on a 5-point Likert scale. The scale anchors ranged from strongly disagree (1) to strongly agree (5). The items in the scales were averaged to create an overall mean for each variable with higher scores indicating higher degrees of each construct.

Leader-member exchange (LMX). Several measures of LMX exist. However, we used the 7-item scale that was developed by Scandura and Graen (1984), as recommended by Gerstner and Day (1997), to measure the relationship quality that subordinates felt they had with their supervisors in both samples. A sample item from this scale was "I know where I stand with my immediate supervisor." The Cronbach alpha for this scale was .90 for sample 1 and .89 for sample 2 .

Job involvement. Seven items adapted from the Lodhal and Kejner (1965) scale were used to measure job involvement in sample 1. The items (e.g. 'I frequently think of my job when doing something else.') produced a Cronbach alpha of .62. A three item scale was used to measure job involvement in sample 2. Two items were adapted from the Buchanan (1964) and Lobel and St. Clair (1992) scales. The three items were "I am very much personally involved in my work," "I live eat and breathe my job," and "The most important things that happen to me involve my job." The reliability for this measure was .67. 


\section{LEADER-MEMBER EXCHANGE AND STRESS}

Role conflict. The 8-item scale developed by Rizzo et al. (1970) was used to measure the extent of role conflict respondents felt existed in their jobs in both samples. A sample item from this scale was "I receive incompatible requests from two or more people." The Cronbach alpha for this scale was .83 for sample 1 and .77 for sample 2 .

Stress. Stress was measured using the 7-item job-induced tension scale developed by House and Rizzo (1972) in sample 1. Items from this scale include, "My job tends to directly affect my health," "If I had a different job, my health would probably improve," and "Problems associated with my job keep me awake at night." The scale has a Cronbach alpha of .83. Six of the seven items from the scale used in sample 1 were used in sample 2 to measure stress. The item "I have felt nervous before attending meetings at work" was excluded from the measure for this sample because members of in this organization did not attend meetings often. The Cronbach alpha for this scale was .88 .

\section{Results}

\section{$\underline{\text { Initial Analyses }}$}

Prior to testing the hypotheses, a confirmatory factor analysis (CFA) for each sample was conducted on the key variables of LMX, job involvement, role conflict, and stress to ensure that the constructs were independent and that the items produced the expected factor structures. CFAs were conducted using LISREL 8.80 with a maximum likelihood estimation and a covariance matrix as input. The first model examined was a four-factor model with items loading on their respective scales: LMX, job involvement, role conflict, and stress. This four-factor model was compared with possible alternative nested models, including (a) a single-factor model, and (b) a three-factor model with the role conflict and stress items loading on one factor because of the significant correlation between the two variables. Overall, after allowing four pairs of items within the same scale to correlate, the hypothesized four-factor model provided an acceptable fit (see Tables 1a and 1b). The hypothesized model provided substantially improved fit over the alternative models with a significant change in chi-square values and improvements in each of the measurement indices.

Table 1a

Confirmatory Factor Analysis of Nested Models for Sample 1

\begin{tabular}{l|cccccccc}
\hline Model & $X^{2}$ & $d f$ & $\Delta d f$ & $X^{2} / d f$ & $\Delta X^{2}$ & $N N F I$ & $C F I$ & $R M S E A$ \\
\hline One-factor & 3566 & 373 & 6 & 9.56 & $2725^{\star \star *}$ & .83 & .85 & .150 \\
Three-factor & 1115 & 370 & 3 & 2.98 & $274^{\star * *}$ & .93 & .93 & .079 \\
Four-factor & 841 & 367 & --- & 2.29 & ---- & .95 & .96 & .057 \\
\hline
\end{tabular}

Note: $N=418$. Change in chi-square is relative to the preceding model in the nested sequence. $\mathrm{NNFI}=$ nonnormed fit index; $\mathrm{CFI}=$ comparative fit index; RMSEA= root-mean-square error of approximation. ${ }^{* * *} p<.001$ 
LEADER-MEMBER EXCHANGE AND STRESS

Table 1b

Confirmatory Factor Analysis of Nested Models for Sample 2

\begin{tabular}{l|cccccccc}
\hline Model & $X^{2}$ & $d f$ & $\Delta d f$ & $X^{2} / d f$ & $\Delta X^{2}$ & $N N F I$ & $C F I$ & $R M S E A$ \\
\hline One-factor & 1411 & 251 & 6 & 5.62 & $1071^{\star * *}$ & .64 & .68 & .20 \\
Three-factor & 496 & 248 & 3 & 2.00 & $156^{* * *}$ & .89 & .90 & .091 \\
Four-factor & 340 & 245 & ---- & 1.39 & ---- & .94 & .95 & .056 \\
\hline
\end{tabular}

Note: $N=134$. Change in chi-square is relative to the preceding model in the nested sequence. $\mathrm{NNFI}=$ nonnormed fit index; $\mathrm{CFI}=$ comparative fit index; RMSEA= root-mean-square error of approximation.

${ }^{* * *} p<.001$

Means, standard deviations, and intercorrelations between the variables of interest are presented in Tables 2 and 3 . As expected, LMX was negatively correlated with role conflict and stress and positively correlated with job involvement. Additionally, a positive correlation existed between role conflict and stress and job involvement and stress.

Although our CFA results indicated that our scales were distinct, we followed the procedure outlined by Fornell and Larcker (1981) and calculated the square root of the average variance explained (AVE) for each of the scales in our study to further explore the discriminant validity of our scales. The rule of thumb states that in order to meet the requirements for discriminant validity, the square root of the AVE must exceed the corresponding latent variable correlations in the same row and column. For example, in Table 2 , the square root of the AVE for role conflict is .61 which is larger than the correlations in the row and column in which it sits. These results indicate that there is discriminant validity among the four latent variables in our study in both samples.

Table 2

Means, Standard Deviations, and Correlations for Sample 1

\begin{tabular}{lcccccc}
\hline \multicolumn{1}{c}{ Variable } & Mean & $S D$ & 1 & 2 & 3 & 4 \\
\hline 1. Leader-member Exchange & 3.42 & 0.99 & .76 & & & \\
2. Job Involvement & 3.53 & 0.58 & $.15^{\star *}$ & .43 & & \\
3. Role Conflict & 2.96 & 0.83 & $-.46^{* *}$ & .03 & .61 & \\
4. Stress & 2.97 & 0.91 & $-.31^{* *}$ & $.28^{* *}$ & .53 & .64 \\
\hline
\end{tabular}

Note: Values on the diagonal are the square root of the average variance explained (Fornell \& Larcker, 1981).

$N=418 .{ }^{*} p<.05 .{ }^{* *} p<.01 .{ }^{* * *} p<.001 .(1-$ tailed).

Table 3

Means, Standard Deviations, and Correlations for Sample 2

\begin{tabular}{lcccccc}
\hline \multicolumn{1}{c}{ Variable } & Mean & $S D$ & 1 & 2 & 3 & 4 \\
\hline 1. Leader-member Exchange & 3.64 & 0.89 & .74 & & & \\
2. Job Involvement & 2.86 & 0.82 & $.49^{* *}$ & .69 & & \\
3. Role Conflict & 2.88 & 0.76 & $-.16^{*}$ & .02 & .54 & \\
4. Stress & 2.70 & 0.97 & $-.15^{\star}$ & $.20^{*}$ & $.48^{* *}$ & .74 \\
\hline
\end{tabular}

Note: The values on the diagonal are the square root of the average variance explained (Fornell \& Larcker, 1981).

$N=134 .{ }^{*} p<.05 .{ }^{* *} p<.01 .{ }^{* * *} p<.001$. (1-tailed) 


\section{Hypotheses Testing}

Baron and Kenny's (1986) three-step procedure for assessing job involvement and role conflict as mediators was followed to test the hypothesis. First, there should be a significant relationship between the independent variable and the mediators; second, there should be a significant relationship between the independent variable and the dependent variable; and third, the mediators should be related to the dependent variable with the independent variable included in the equation. If the main effect of the independent variable on the dependent variable is reduced but still significant, then partial mediation exists; if the main effect is reduced to a non-significant level, then full mediation exists.

Results for the mediation tests can be found in Tables 4 and 5. In step 1, the mediators (job involvement and role conflict) were regressed on the independent variable (LMX). The beta weights for LMX were significant for both job involvement and role conflict in both samples. The first requirement for mediation was satisfied and provided support for Hypothesis 1 and 2. In step 2, the dependent variable (stress) was regressed on the independent variable (LMX) and the result was significant in both samples. The third mediation step was tested by regressing stress on job involvement and role conflict with LMX being included in the equation. The beta weight for LMX for sample $1(b=-.15, p<.001)$ was significant, although smaller than it was when job involvement and role conflict were excluded. The beta weight for LMX for sample $2(b=-.09, p>.05)$ was not significant. Therefore, Hypothesis 3 and 4 were supported with partial mediation in Sample 1 and full mediation in Sample 2.

Table 4

Regression Analysis Results for Mediation for Sample 1

\begin{tabular}{|c|c|c|c|c|}
\hline & $F$ & $d f$ & Adjusted $R^{2}$ & $b$ \\
\hline $\begin{array}{l}\text { Step } 1 \text { - Mediator: Job Involvement } \\
\text { LMX }\end{array}$ & 9.97 & 1,416 & .02 & $.15^{\star *}$ \\
\hline $\begin{array}{l}\text { Step1 - Mediator: Role Conflict } \\
\text { LMX }\end{array}$ & 110.15 & 1,416 & .21 & $-.46^{* * *}$ \\
\hline $\begin{array}{l}\text { Step } 2 \text { - Dependent Variable: Stress } \\
\text { LMX }\end{array}$ & 44.67 & 1,416 & & $-.31^{* * \star}$ \\
\hline $\begin{array}{l}\text { Step } 3 \text { - Dependent Variable: Stress } \\
\text { LMX } \\
\text { Job Involvement } \\
\text { Role Conflict }\end{array}$ & 79.065 & 3,414 & & $\begin{array}{l}-.15^{\star \star \star} \\
.29^{\star \star \star} \\
.45^{\star \star \star}\end{array}$ \\
\hline
\end{tabular}

Note. LMX = leader-member exchange (1-tailed)

${ }^{*} p<.05 .{ }^{* *} p<.01$ 
LEADER-MEMBER EXCHANGE AND STRESS

Table 5

Regression Analysis Results for Mediation for Sample 2

\begin{tabular}{l|cccc}
\hline & $F$ & $d f$ & Adjusted $R^{2}$ & $b$ \\
\hline $\begin{array}{l}\text { Step 1 - Mediator: Job Involvement } \\
\text { LMX }\end{array}$ & 42.54 & 1,134 & .24 & $.49^{* *}$ \\
Step1 - Mediator: Role Conflict & & & & \\
LMX & 3.35 & 1,132 & .21 & $-.16^{*}$ \\
Step 2 - Dependent Variable: Stress & & & & \\
LMX & 3.79 & 1,134 & .02 & $-.15^{*}$ \\
& & & & \\
Step 3 - Dependent Variable: Stress & & & &. .11 \\
LMX & 3.79 & 3,132 & .41 & $.46^{* *}$ \\
Job Involvement & 15.85 & & & \\
Role Conflict & 32.01 & & & \\
& & & &
\end{tabular}

Note. LMX = leader-member exchange (1-tailed)

${ }^{*} p<.05,{ }^{* *} p<.01,{ }^{* * *} p<.001$

In addition, Sobel tests were conducted to evaluate the significance of indirect effects (McKinnon, Lockwood, Hoffman, West, \& Sheets, 2002; Sobel, 1982). Sobel tests involve calculating the degree of the unstandardized indirect effect and its additional standard error. The ratio of the indirect effect over its standard error, the Sobel statistic, is subsequently compared with a $z$ distribution to determine the statistical significance of the indirect effect. Results from the Sobel tests indicate that the indirect effects of LMX on stress are in the anticipated directions and are statistically significant for sample 1 (job involvement $-z=2.78, p=.005$; role conflict $-z=-8.00, p=.000$ ) and sample 2 (job involvement $z=2.39$, $p=.008$; role conflict $z=4.36, p=.000$ ).

\section{Treatment for Common Method Variance}

All of the data used in this study were collected from the same source at the same time. One consequence of this design is the potential for common method variance (CMV) to impact the results. Therefore, several steps were taken to minimize common method biases by following procedural remedies offered by Podsakoff et al. (2003). First, detailed information about the precautions taken to ensure the confidentiality of the respondents was presented to decrease socially desirable responses and to increase respondent openness. Second, respondents were assured that there were no right or wrong answers, in an effort to decrease evaluation apprehension.

In addition, the degree to which CMV existed in the data was examined by estimating and comparing nested SEM models using LISREL 8.80 with a maximum likelihood estimation and a covariance input. The first step was to estimate a full measurement model that included a factor for each of the four key variables: LMX, role conflict, job involvement, and stress. Then, a model that included a fifth latent variable to represent a method factor was estimated, allowing all 29 items to load on this uncorrelated factor. According to Williams, Cote, and Buckley (1989), if the fit of the measurement model is significantly improved by the addition of an uncorrelated method factor, then CMV may be a concern. For sample 1, the full measurement model $(\mathrm{CFI}=.96$; NNFI $=.95$; RMSEA $=.057)$ fit the data. The fit statistics when adding an uncorrelated method factor showed improvement $(\mathrm{CFI}=.98$; NNFI $=.97$; RMSEA = .043). The chi-square difference test between the measurement model and the method factor model was significant $\left(X_{\text {diff }}^{2}(29)=256, p<.01\right)$. These results suggest that adding a method factor improved the measurement model. For sample 2, the full measurement model $(\mathrm{CFI}=.95 ; \mathrm{NNFI}=.94$; RMSEA $=.056)$ fit the data well. The fit statistics when adding an uncorrelated method factor showed 
improvement $(\mathrm{CFI}=.96 ; \mathrm{NNFI}=.95 ; \mathrm{RMSEA}=.051)$. The chi-square difference test between the measurement model and the method factor model was significant $\left(\mathrm{X}_{\text {diff }}^{2}(29)=49, p<.05\right)$. These results suggest that adding a method factor improved the measurement model.

To determine the degree of influence of CMV, the variance explained by the method factor can be calculated. Specifically, the sum of the squared loadings can be used to index the total amount of variation due to the method factor. CMV accounted for only $10 \%$ of the total variance in the sample 1 and $8 \%$ of the variance in sample 2 , which is much less than the $25 \%$ observed by Williams et al. (1989). The results of the analyses suggest that the models tested benefit from the addition of a method factor. However, the increase in fit is minimal and the method factor accounts for a small amount of variation in the data. Therefore, while CMV is present in the data our CMV results offer evidence that the relationships reported represent substantive rather than artifactual effects.

\section{Discussion}

Previous research examining the relationship between LMX and stress has found that both a negative linear (Nelson et al, 1998) and a U-shaped curvilinear relationship (Harris \& Kacmar, 2006) exist between LMX and stress. The purpose of this research was to determine the process through which high-quality LMX members experience high levels of stress. Specifically, role conflict and job involvement were considered as mediators of the LMX and stress relationship. As predicted, across two samples, LMX was negatively related to role conflict and positively related to job involvement and role conflict and job involvement were both significantly related to stress.

The mediation effects uncovered involved role conflict and job involvement in the relations between LMX and stress. These results suggest that role theory (Kahn et al., 1964) accurately describes the potential role stressors that may lead to stress. The mediation effects of job involvement on the LMX stress relationship suggest that social exchange theory (Gouldner, 1960) appropriately describes the increased level of job involvement that occurs as high-quality LMX members seek to reciprocate the additional communication, information, and support received from their supervisors.

\section{$\underline{\text { Strengths and Limitations }}$}

This study has several strengths that should be noted. First, this study extends the existing research on LMX in several ways. We contributed to the current literature by examining the stress outcome (Liden et al., 1997). Research examining the relationship between LMX and stress has been limited. Second, this study also extended previous research by explaining the mechanisms that influence high-levels of stress in high-quality LMX members. This study replicated previous research by showing that high-quality LMX members experience low levels of role conflict (Nelson et al., 1998). It also extends the current literature in finding that high-quality LMX members experience increased levels of stress through a different process, job involvement.

This research has several limitations that present opportunities for future research. First, although our analyses indicated this is not a significant problem, we measured predictor and criterion variables for the same source, presenting the potential of CMV. The use of self-rated work behaviors also presents a limitation, as previous research has demonstrated that this form of measurement is subject to self-rating leniency with self-rated behavior often being overinflated and having low correlations with actual behavior (Dunning, Heath, \& Suls, 2004; Xie, Roy, \& Chen, 2006). Therefore, future research should include data collected from multiple sources and work behaviors collected from alternative sources. Second, the reliability of the job involvement measures is below the traditional cut-off points. Therefore, future research should measure job involvement with a more reliable scale. Third, this study only examined job involvement and role conflict as mediators of the LMX stress relationship. Additional role stressors, such as role overload and work-family conflict, also may explain the process by which high-quality LMX members experience stress.

\section{$\underline{\text { Future Research and Practical Implications }}$}


The findings of this research suggest several avenues for future research. In particular, whereas the results of this study provide some evidence for the potential costs of high-quality LMX relationships, a vast majority of research has found that being a trusted subordinate has its rewards. For example, employees who enjoy high-quality LMX relationships receive more support, autonomy, and higher performance ratings (Gernster \& Day, 1997). Shirom and Mayer (1993) proposed that the rewards related to taking on additional roles often outweigh any stress that doing so might produce. Accordingly, whereas high-quality LMX employees may experience more stress as a result of increased job involvement, the costs of this relationship may be offset by the benefits of more favorable performance appraisals, increased autonomy, and more rapid advancement. It would be useful for future research to further extend this model to see if the stress experienced by high-quality LMX members results in increased turnover levels and reduced organizational commitment and job satisfaction. Second, it also would be useful for researchers to understand the ways in which employees evaluate the costs and benefits of being in high-quality LMX relationships.

Third, the increased job involvement that subordinates may engage in as a result of high-quality LMX relationships is comparable to the construct of organizational citizenship behaviors (OCBs), which is positively related to LMX quality (Rupp \& Cropanzano, 2002; Hofmann, Morgeson, \& Gerras, 2003). Therefore, future research should examine LMX quality, job involvement, stress, and OCBs in a study to explore the interrelationships among these variables. Finally, previous researchers have found that LMX relationships are best described as long-term (Liden, Wayne \& Stilwell, 1993). Therefore, researchers examining this process over the long term may provide different perspectives.

The results of this study indicate that while high-quality LMX members do not experience stress as a result of role conflict, they indeed experience stress through a different mechanism, job involvement. If engaging in high-quality LMX relationships has negative implications for employees, this environment, may be less attractive to individuals. Feelings of increased stress among employees could produce higher levels of turnover and also make it more difficult to attract new employees. Practically speaking, employers should find ways to eliminate these adverse outcomes. Specifically, organizations should provide training that informs supervisors of the potential negative results of giving increased attention to a limited number of subordinates.

Subordinates should be aware that high-quality LMX relationships with their supervisor may have potential disadvantages in addition to its benefits. For instance, while subordinates who are involved in high-quality relationships receive increased levels of exposure to and opportunities with their supervisors, the increased amount of attention given to these individuals may result in the subordinate's high identification with the job. This increased identification can lead to the subordinate working long hours and taking on additional assignments. As a result of the social exchange perspective of the high-quality LMX relationship occurring, these members may feel overwhelmed by fulfilling the requests from their supervisor and may subsequently experience stress.

\section{$\underline{\text { Conclusion }}$}

A number of studies have indicated that high-quality LMX members are afforded additional opportunities and receive more benefits when compared to low-quality LMX members. Researchers also have suggested that high-quality LMX members experience reduced amounts of stress as a result of increased communication and information that they receive from supervisors. Results from this study indicate that in addition to the benefits received as a result of high-quality LMX relationships, negative outcomes such as stress also may be experienced. Future research should seek to obtain a further understanding of these relationships and explore the additional organizational outcomes that may result from this process. 


\section{LEADER-MEMBER EXCHANGE AND STRESS}

\section{References}

American Institute of Stress. (2007). Job stress. Retrieved from http://www.stress.org/job.htm. Accessed 9/7/09.

Anderson, S. E., \& Williams, L. J. (1996). Interpersonal, job, and individual factors related to helping processes at work. Journal of Applied Psychology, 81, 282-296.

Baron, R. M., \& Kenny, D. (1986). The moderator-mediator variable distinction in social psychological research. Journal of Personality and Social Psychology, 51, 1173-1182.

Blau, P. (1964). Exchange and power in social life. New York: Wiley.

Brown, S. P. (1996). A meta-analysis and review of organizational research on job involvement. Psychological Bulletin, 120, 235-255.

Buchanan, B. (1964). Building organizational commitment: The socialization of managers in work organizations. Administrative Science Quarterly, 19, 533-546.

Carlson, D. S., \& Perrewe, P. L. (1999). The role of social support in the stressor-strain relationship: An examination of work-family conflict. Journal of Mangement, 25, 513-540.

Chen, Z., Lam, W., \& Zhong, J. A. (2007). Leader-member exchange and member performance: A new look at individual-level negative feedback-seeking behavior and team-level empowerment climate. Journal of Applied Psychology, 92, 202-212.

Cropanzano, R., \& Mitchell, M. S. (2005). Social Exchange Theory: An Interdisciplinary Review. Journal of Management, 31, 874-900.

Dansereau, F., Graen, G., \& Haga, W. J. (1975). A vertical dyad linkage approach to leadership within formal organizations: a longitudinal investigation of the role making process. Organizational Behavior and Human Performance, 13, 46-78.

Deluga, R. J. (1998). Leader-member exchange quality and effectiveness ratings. Group and Organization Management, 23, 189-216.

Dienesch, R. M., \& Liden, R. C. (1986). Leader-member exchange model of leadership: a critique and further development. Academy of Management Review, 11(3), 618-634.

Dunning, D., Heath, C., \& Suls, J. M. (2004). Flawed self-assessment: Implications for health, education, and the workplace. Psychological Science in the Public Interest, 5, 69-106.

Fornell, C., \& Larker, D. (1981). Evaluating structural equation models with unobservable variables and measurement error. Journal of Marketing Research, 18, 39-50.

Ganster, D. C., \& Schaubroeck, J. (1991). Work stress and employee health. Journal of Management, 17, 235-271.

Gerstner, C. R., \& Day, D. V. (1997). Meta-analytic review of leader-member exchange theory: correlates and construct issues. Journal of Applied Psychology, 82(6), 827-844.

Gouldner, A. W. (1960). The norm of reciprocity: A preliminary statement. American Sociological Review, 25, 161-178.

Graen, G. (1976). Role making process within complex organizations. In M. Dunnette (Ed.), Handbook of industrial and organizational psychology (pp. 1201-1245). Chicago: Rand McNally.

Graen, G., \& Cashman, J. E. (1975). A role making model of leadership in formal organizations: a developmental approach. In J. G. Hunt \& L. L. Larson (Eds.), Leadership Frontiers (pp. 143-165). Kent: Kent State University.

Graen, G., \& Scandura, T. A. (1987). Toward a psychology of dyadic organizing. In L.L. Cummings \& B.M. Staw (Eds.), Research in organizational behavior, 9:175-208. Greenwich, CT: JAI Press.

Graen, G., \& Uhl-Bien, M. (1995). Relationship-based approach to leadership: Development of leadermember exchange (LMX) theory of leadership over 25 years: Applying a multi-level multi-domain perspective. Leadership Quarterly, 6, 219-247.

Harris, K. J. \& Harris, R. B., \& Brouer, R. L. (2009). LMX and subordinate political skill: Direct and interactive effects on turnover intentions and job satisfaction. Journal of Applied Social Psychology, 39, 2373-2395.

Harris, K. J., \& Kacmar, K. M. (2006). Too much of a good thing: The curvilinear effect of leader-member exchange on stress. The Journal of Social Psychology, 146(1), 65-84.

Hart, P. M. \& Cooper, C. L. (2001). Occupational stress: Toward a more integrated framework. In N. Anderson, D.S. Ones, H.K. Sinangil, \& C. Viswesvaran (Eds.), Handbook of industrial, work, and organizational psychology, (pp. 93-114). Thousand Oaks, CA: Sage. 
Hofmann, D. A., Morgeson, F. P., \& Gerras, S. J. (2003). Climate as a moderator of the relationship between leader-member exchange and context specific citizenship: Safety climate as an exemplar. Journal of Applied Psychology, 88, 170-178.

House, R. J., \& Rizzo, J. R. (1972). Role conflict and ambiguity as critical variables in a model of organizational behavior. Organizational Behavior and Human Performance, 7, 467-505.

Jackson, S. E., \& Schuler, R. S. (1985). A meta-analysis and conceptual critique on research on role ambiguity and role conflict in work settings. Organizational Behavior and Human Performance, $33,1-21$.

Janssen, O. (2003). Innovative behavior and job involvement at the price of conflict and less satisfactory relations with co-workers. Journal of Occupational and Organizational Psychology, 76, 347-364.

Judge, T. A., \& Colquitt, J. A. (2004). Organizational justice and stress: The mediating role of work-family conflict. Journal of Applied Psychology, 89, 395-404.

Jex, S. M., \& Beehr, T. A. (1991). Emerging theoretical and methodological issues in the study of workrelated stress. In G.R. Ferris and K.M. Rowland (Eds.), Research in personnel and human resources management, 9: 311-365. Greenwich, CT: JAI Press.

Kacmar, K. M., Witt, L. A., Zivnuska, S., \& Gully, S. (2003). The impact of leader-member exchange on communication type, frequency, and performance. Journal of Applied Psychology, 88, 764-772.

Kahn, R. L., \& Byosiere, P. (1992). Stress in organizations. In M.D. Dunnette \& L.M. Hough (Eds.), Handbook of industrial and organizational psychology, (vol. 3:pp. 571-650). Palo Alto, CA: Consulting Psychologists Press.

Kahn, R. L., Wolfe, D. M., Quinn, R. P., Snoek, J. D., \& Rosenthal, R. A. (1964). Organizational stress: Studies in role conflict and ambiguity. New York: Wiley.

Kanungo, R. N. (1982). Measurement of job and work involvement. Journal of Applied Psychology, 67, 341-349.

Katz, D., \& Kahn, R. L. (1978). The social psychology of organizations $\left(2^{\text {nd }}\right.$ ed.). New York: Wiley.

Lagace, R. R., Castleberry, S. B., \& Ridnour, R. E. (1993). An exploratory sales force study of the relationship between leader-member exchange and motivation, role stress, and manager evaluation. Journal of Applied Business Research, 9, 110-119.

Liden, R. C. \& Maslyn, J. M. (1998). Multidimensionality of leader-member exchange: An empirical assessment through scale development. Journal of Mangement, 24, 43-72.

Liden, R. C., Sparrowe, R. T., \& Wayne, S. J. (1997). Leader-member exchange theory: The past and potential for the future. In G.R. Ferris (Ed.), Research in personnel and human resource management (vol.15, pp.47-120). Greenwich, CT: JAI Press.

Liden, R. C., Wayne, S. J., \& Stilwell, D. (1993). A longitudinal study on the early development of leader member exchanges. Journal of Applied Psychology, 78, 662-674.

Lobel, S. A. \& St. Clair, L. (1992). Effects of family responsibilities, gender, and career Identity salience on performance outcomes. Academy of Management Journal, 35, 1057-1069.

Lodahl, T. M., \& Kejner, M. (1965). The definition and measurement of job involvement. Journal of Applied Psychology, 49, 24-33.

MacKinnon, D. P., Lockwood, C. M., Hofman, J. M., West, S. G., \& Sheets, V. (2002). A comparison of methods to test mediation and other intervening variable effects. Psychological Methods, 7, 83104.

Mudrack, P. E. (2004). Job involvement, obsessive-compulsive personality traits, and workaholic behavioral tendencies. Journal of Organizational Change Management, 17, 490-508.

Nelson, D., Basu, R., \& Purdie, R. (1998). An examination of exchange quality and work stressors in leader-follower dyads. International Journal of Stress Management, 5, 103-113.

Parasuraman, S. \& Simmers, C. A. (2001). Type of employment, work-family conflict and well-being: a comparative study. Journal of Organizational Behavior, 22, 551-568.

Podsakoff, P. M., MacKenzie, S. B., Lee, J., \& Podsakoff, N. P. (2003). Common method biases in behavioral research: A critical review of the literature and recommended remedies. Journal of Applied Psychology, 88, 879-903.

Rizzo, J. R., House, R. J., \& Lirtzman, S. I. (1970). Role conflict and ambiguity in complex organizations. Administrative Science Quarterly, 15, 150-163.

Rupp, D. E., \& Cropanzano, R. (2002). The mediating effect of social exchange relationships in predicting workplace outcomes from multifoci organizational justice. Organizational Behavior and Human Decision Processes, 89, 925-946. 
Scandura, T. A. \& Graen, G. B. (1984). Moderating effects of initial leader-member exchange status on the effects of leadership intervention. Journal of Applied Psychology, 69, 428-436.

Schaubroeck, J., Cotton, J., \& Jennings, K. (1989). Antecedents and consequences of role stress: A covariance structure analysis. Journal of Organizational Behavior, 10, 35-58.

Schriescheim, C. A., Castro, S. L., \& Cogliser, C. C. (1999). Leader-member exchange (LMX) research: A comprehensive review of theory, measurement, and data-analytic practices. Leadership Quarterly, 10, 63-113.

Settoon, R. P., Bennett, N., \& Liden, R. C. (1996). Social exchange in organizations: Perceived organizational support, leader member exchange, and employee reciprocity. Journal of Applied Psychology, 81, 219-227.

Shirom, A., \& Mayer, A. (1993). Stress and strain among union lay officials and rank-and-file members. Journal of Organizational Behavior, 14, 401-413.

Sobel, M. E. (1982). Asymptotic intervals for indirect effects in structural equation model. In S. Leinhart (Ed.), Sociological methodology (pp. 290-312). San Francisco: Jossey-Bass.

Tanner, Jr. J. F., \& Castleberry, S. B. (1990). Vertical exchange quality and performance: Studying the role of the sales manager. Journal of Personal Selling \& Sales Management, 10, 17- 27.

Tanner, Jr. J. F., Dunn, M. G., \& Chonko, L. B. (1993). Vertical exchange and salesperson stress. Journal of Personal Selling \& Sales Management, 13, 27-35.

Uhl-Bien, M., \& Maslyn, J. (2003). Reciprocity in manager-subordinate relationships: Components, configurations, and outcomes. Journal of Management, 29, 511-532.

Williams, L. J., Cote, J. A., \& Buckley, M. R. (1989). Lack of method variance in self-reported affect and perceptions of work: Reality or artifact? Journal of Applied Psychology, 74, 462-468.

Xie, J. L., Roy, J. P., \& Chen, Z. (2006). Cultural and individual difference in self-rating behavior: An extension and refinement of the cultural relativity hypothesis. Journal of Organizational Behavior, $27,341-364$. 
Reproduced with permission of the copyright owner. Further reproduction prohibited without permission. 